\title{
Silylated functionalized
}

montmorillonite clay for

nanocomposite preparation

David P. PENALOZA JR. - Chemistry Department, College of Science, De La Salle University, Manila, Philippines • david.penaloza.jr@dlsu.edu.ph

ThomAS AP SEERY - Chemistry Department and Polymer Program, Institute of Materials Science, University of Connecticut, Connecticut, USA - Email: thomas.seery@uconn.edu

Érkezett: 2018. 05. 24. - Received: 24. 05. 2018. - https://doi.org/10.14382/epitoanyag-jsbcm.2018.26

David P. PENALOZA Jr.

is an associate professor in the Chemistry Department, College of Science, De La Salle

University. His research interests focus on self-assembled systems and nanostructured materials.

Thomas AP SEERY is an associate professor in the Chemistry Department and the Polymer Program, Institute of Materials Science (IMS), University of Connecticut. He previously served as the Polymer Program director at IMS. His research interests include polymer synthesis at surfaces and physical chemistry of polymers in solution.

\section{Abstract}

Hydrothermal silylation reaction between a norbornenyl-bearing chlorosilane coupling agent and the silanol groups of the montmorillonite (MMT) clay results in a functionalized organoclay. To do this, the clay samples were previously modified using different alkyl ammonium surfactants prior to silylation. Apparently, the different surfactant modifiers used led to different clay morphologies for the silylated functionalized clay templates as confirmed by x-ray diffraction and elemental micro-analysis.

Keywords: silylation, surface modification, silicate clay, nanocomposite, organoclay

Kulcsszavak: szilanizálás, felület modifikálás, szilikát agyag, nanokompozit, szerves agyag

\section{Introduction}

A polymer-clay nanocomposite represents a new class of hybrid materials composed of an organic polymer matrix with an inorganic clay acting as a filler material having at least one dimension in the nanometer range. A fully exfoliated, individual clay platelet is about a nanometer in thickness. At this length scale, the presence of these individual nanometer thin platelets dispersed in the polymer matrix even at a low amount of the silicate filler ( $<10 \%$ by wt) can impact the resulting hybrid organic-inorganic material to exhibit greatly enhanced and new properties relative to the neat polymer [15]. These new and enhanced properties observed for these nanomaterials have found numerous applications and have attracted the attention of both the academe and the industries.

Among the clay fillers, the montmorillonite (MMT) clay is the usual choice in preparing most polymer-clay nanocomposites because of its individual nanometer-"thick" platelets, extremely large surface areas [2], rich intercalation and surface chemistry [6-7]. Further, this type of clay is universally abundant in nature and can be obtained in pure form at a low cost.

An MMT clay, being hydrophilic in nature, obviously would only be miscible with hydrophilic polymers like poly(ethylene oxide), poly(vinyl alcohol), etc.. Generally, it would be very difficult to mix this clay with hydrophobic polymers because of its pristine hydrophilic nature. One way of increasing the favorable interaction between organic molecules and clay surfaces is by introducing some hydrophobic groups onto the layer surfaces [8]. This method of clay modification can be possible with the reaction of silanes with the silanol groups found in the clay layered structure [6, 9-12]. The introduced technique makes use of the existing silanol groups found in the clay structure to react with organosilane agents. Silanol groups $(\mathrm{Si}-\mathrm{OH})$ are located on the clay edges due to broken edges and crystalline defects [13-18]. Using a chloro- or alkoxysilanes as modifying agents, several functionalities can be introduced to the clay [19]. Unlike the ion-exchanged clays, the covalently modified clays achieved through the hydrosilylation of the silanol groups are more thermally stable $[9,15]$. More importantly, the characteristics of the modified clays can be easily fine-tuned through the introduction of various end groups of the silane modifiers [14, 20-23].

\section{Experimental}

\subsection{Materials}

Hexanes (98.5\%) were purchased from Acros Organics. Tetrahydrofuran (THF) (99\%) and methanol (absolute) were purchased from J.T. Baker Inc. Decyltrimethylammonium bromide (DTAB) was obtained from Aldrich. [(Bicycloheptenyl) ethyl] dimethylchlorosilane was obtained from Gelest Inc.

Cloisite15A clay and sodium montmorillonite clay were obtained from Southern Clay Products, Inc.

\subsection{Preparation of MMT_C10 clay via ion-exchange reaction}

Montmorillonite clay (MMT) was reacted first with an alkyl ammonium halide to hydrophobize the clay. This was accomplished by an ion exchange reaction between clay and decyltrimethylammoniumbromide, $\mathrm{CH}_{3}\left(\mathrm{CH}_{2}\right)_{8} \mathrm{CH}_{2} \mathrm{~N}^{+}\left(\mathrm{CH}_{3}\right)_{3} \mathrm{Br}$ (DTAB). A $5.0 \mathrm{~g}$ MMT was added to $500 \mathrm{~mL}$ of deionized water, stirred for 2 hours and sonicated for 3 hours. $1.5 \mathrm{~g}$ of DTAB was then added and stirred for 24 hours. The ion exchanged clay (MMT_C10) was separated by centrifuge, washed several times with de-ionized water to remove excess DTAB, air-dried prior to vacuum drying at $100^{\circ} \mathrm{C}$.

\subsection{Silylation of the host silicate clays}

Two MMT clay derivatives were considered for silylation: (1) commercial organoclay Cloisite15A from the Southern Clay Products, Inc. and (2) an MMT clay that we previously modified via io-exchange reaction using decyltrimethyl ammonium bromide, $\mathrm{CH}_{3}\left(\mathrm{CH}_{2}\right)_{8} \mathrm{CH}_{2} \mathrm{~N}^{+}\left(\mathrm{CH}_{3}\right)_{3} \mathrm{Br}$. 
The organoclay was vacuum-dried at $50{ }^{\circ} \mathrm{C}$ prior to silylation. A silane coupling agent having a norbornene moiety, [(bicycloheptenyl)ethyl] dimethylchlorosilane, was used to functionalize the clay. A $5.0 \mathrm{~g}$ sample of the organoclay was placed in an air-free three-neck round bottom flask and flushed with nitrogen for few minutes. $150 \mathrm{~mL}$ of dry hexane was then added to the sample and the mixture was stirred under static nitrogen for 10 minutes.

Then, $5 \mathrm{~mL}$ of norbornene-chlorosilane was added to the flask and the mixture was refluxed under nitrogen for $48 \mathrm{~h}$. The final product (silylated organoclay) was then filtered off and repeatedly washed with hexane, before being dried at 60 ${ }^{\circ} \mathrm{C}$ for $24 \mathrm{~h}$ under vacuum.

\subsection{Instrumentation}

\subsubsection{X-ray diffraction (XRD)}

The X-ray diffraction analyses in the small-angle $(2 \theta=0$ 10) region were performed using a Bruker GADDS X-ray diffractometer. The beam was $\mathrm{Cu} \mathrm{K}_{\alpha}(\lambda=0.154 \mathrm{~nm})$ operated at $40 \mathrm{kV}$ and $40 \mathrm{~mA}$.

\subsubsection{Transmission Electron Microscopy (TEM)}

TEM was employed to observe the morphology of the organoclay. TEM micrographs were obtained using FEI Spirit Twin transmission electron microscope. Samples for TEM observation were dissolved in THF and a 5-ug aliquot was solution cast onto carbon-coated grids.

\subsubsection{Carbon and Nitrogen Content Analysis}

The percentage content of carbon and nitrogen of the organoclay materials before and after the silylation process was determined using Elementar CHNOS Elemental Analysis equipment.

\section{Results and discussion}

One of the inorganic fillers often considered to prepare polymer nanocomposites is layered silicate clay. Among the layered clays, the montmorillonite (MMT) clay is most often used. It has a layered structure made up of stacks of nanometer"thick" silicate platelets. Fig. 1 shows the XRD pattern and TEM micrograph of a pristine sodium montmorillonite $\left(\mathrm{Na}^{+}-\right.$ MMT) clay. The unmodified clay contained sodium $\left(\mathrm{Na}^{+}\right)$ions found in the interlayers of the MMT layered structure. Based on the XRD measurement of the clay, the $\mathrm{Na}^{+}-\mathrm{MMT}$ clay has a $\mathrm{d}$ spacing $\left(\mathrm{d}_{001}\right)$ of $1.18 \mathrm{~nm}$. The value of the $\mathrm{d}_{001}$ spacing is calculated using the Bragg's equation based from the $2 \theta$ position of the (001) diffraction peak (Fig. 1.a). Considering that one silicate platelet has a thickness of $0.96 \mathrm{~nm}$ and the calculated $\mathrm{d}_{001}$ spacing of $1.18 \mathrm{~nm}$, an interlayer spacing due to the sodium ions found in the MMT galleries equal to $0.22 \mathrm{~nm}$ can be calculated. This value $(0.22 \mathrm{~nm})$ is larger than the reported value for the diameter of a sodium ion. This is because the ions originally found in the interlayers of the MMT structure most often are hydrated. The TEM micrograph (Fig. 1.b) of the clay shows that along the edges of the clay sample (as pointed by the arrow), the stacking of a number of silicate platelets can be clearly observed, showing the layered morphology of the MMT clay.
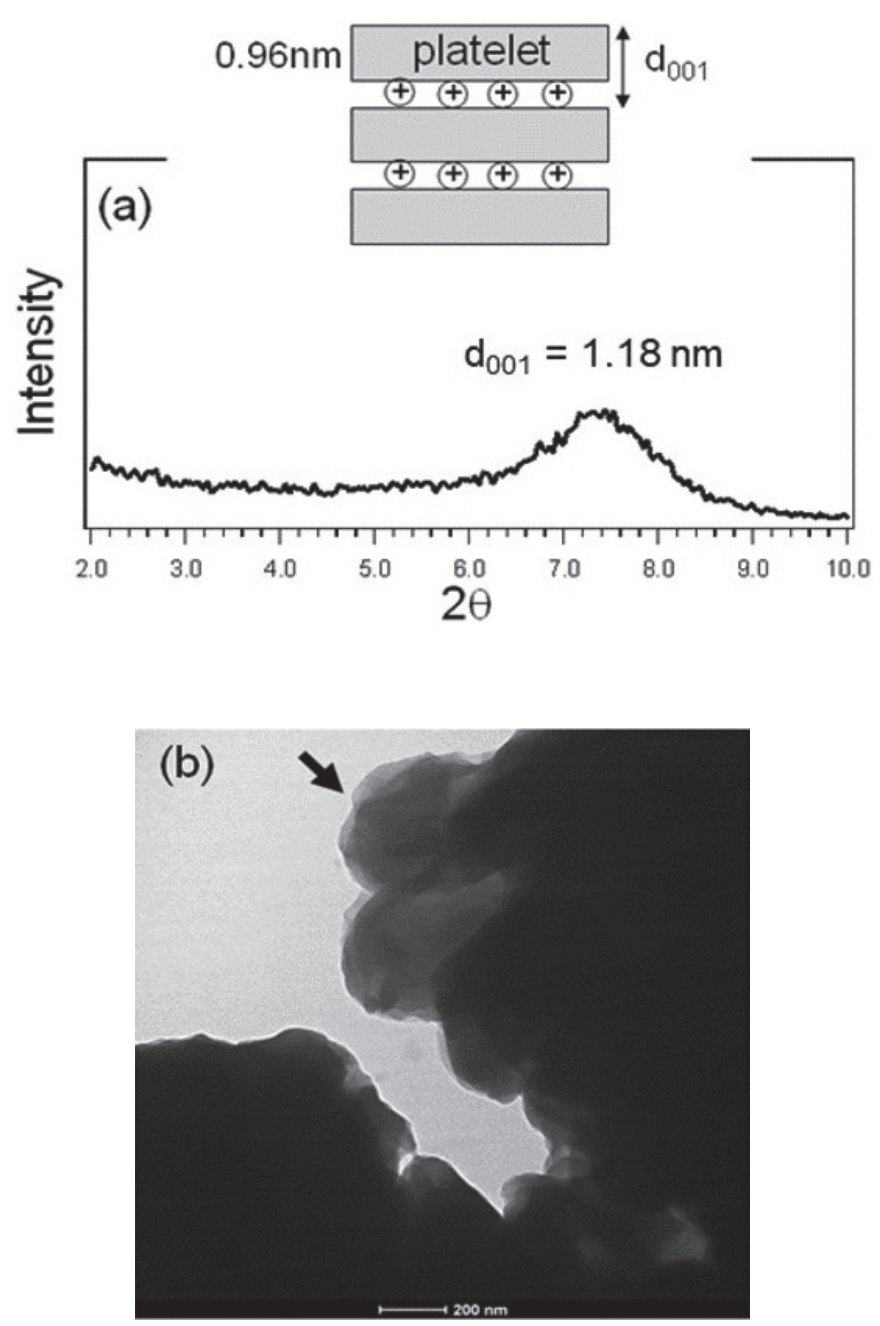

Fig. 1. (a) XRD profile and (b) TEM micrograph of a sodium montmorillonite $\left(\mathrm{Na}^{+}-\right.$ $M M T$ ) clay

1. ábra Nátrium montmorillonit $\left(\mathrm{Na}^{+}-\mathrm{MMT}\right)$ agyag (a) röntgendiffraktogramja és (b) TEM mikroszkópos képe

Our research group's interest is in the preparation of nanostructured hybrid materials with covalently tethered polymer architecture [24-27]. In our most recent work involving clay-based polymer nanocomposite preparation, norbornenebearing silanes are attached on the surface and edge of an MMT organoclay, and the polymerization of norbornene directly from the organoclay results in the successful formation of an exfoliated silicate clay-polymer nanocomposite as confirmed by XRD and TEM. To achieve this, we initially modify Cloisite15A clay, a commercial MMT organoclay from Southern Clay Products, Inc. that was previously modified with ammonium salt bearing naturally occurring tallows. In this previously published work, we have demonstrated that norbornene-bearing initiators can be successfully grafted via covalent binding to the MMT clay as confirmed by the results of the fourier-transform infrared (FTIR), ${ }^{29} \mathrm{Si}$ solid-state nuclear magnatec resonance $\left({ }^{29} \mathrm{Si}-\mathrm{NMR}\right)$ spectroscopic measurements and thermogravimetric analysis (TGA) [26]. 
There is a need, however, to evaluate if the silylation reaction between the norbornene-chlorosilane and the silanols of the MMT clay modified the surface of the clay template or only the edges (Fig. 2). This is important in our case since modifying the clay surface would enable us to facilitate the polymerization between the galleries of the host clay template. To do this, we have compared the XRD profiles of the MMT organoclays before and after the silylation reaction as well as their nitrogen content. The silylation reaction would change the distance between the platelets and shift the $\mathrm{d}_{001}$ which can be detected by XRD. The nitrogen content of the organoclays before and after the silylation reaction will help us monitor if some of the previously intercalated ammonium modifiers are lost during the silylation process.

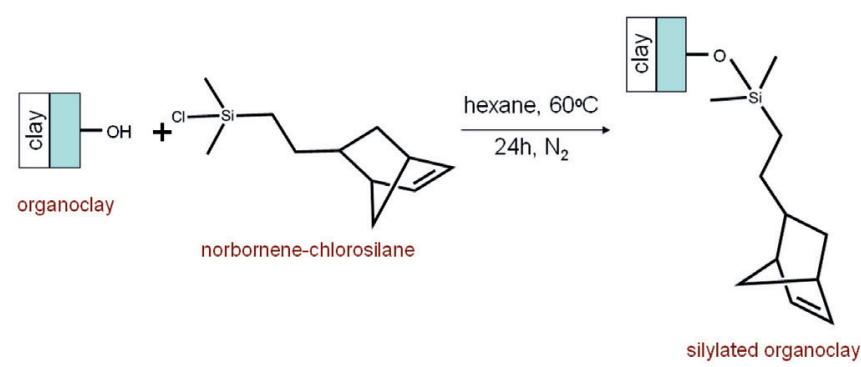

Fig. 2. Scheme of the silylation process between norbornene-chlorosilane and MMT clay

2. ábra Szilanizálás sémája norbornén-kloroszilán és MMT agyag kölcsönhatásában

\subsection{X-ray diffraction}

The basal spacing $\left(\mathrm{d}_{001}\right)$ of the clay samples was determined using Bragg's Law: $d_{001}=\lambda /(2 \sin \theta)$; where $\lambda$ represents the wavelength of the X-ray $\left(1.5418 \mathrm{~A}^{\circ}\right)$. An X-ray diffraction (XRD) spectrum is usually a plot of the scattering angle, $2 \theta$, against an arbitrary intensity of a diffraction peak. Fig. 3 represents the XRD patterns of the nonsilylated and silylated Cloisite15A clays.
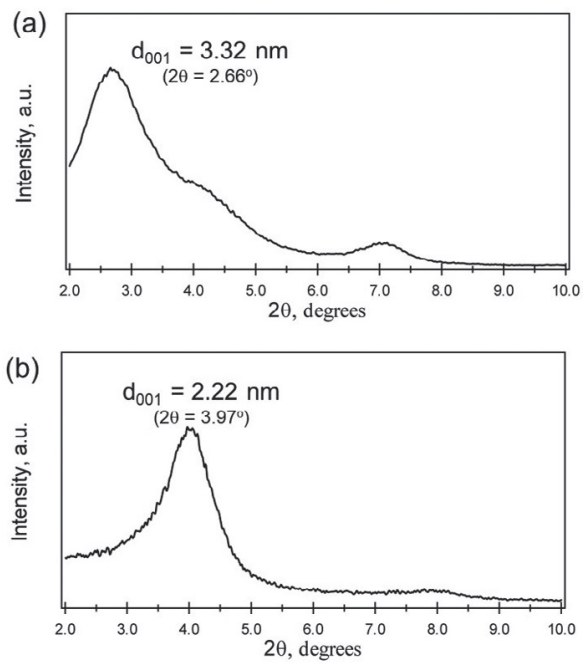

Fig. 3. XRD patterns of the (a) ion-exchanged montmorillonite clay (Cloisite15A) and (b) silylated Cloisite15A (Cloisite15A_sil)

3. ábra Röntgendiffraktogramok (a) ioncserélt montmorillonit agyag (Cloisite15A) és (b) szilanizált Cloisite15A (Cloisite15A_sil)

The XRD spectrum of the nonsilylated organoclay, Cloisite15A, shows a broad peak at around $2 \theta=2.66^{\circ}$ that corresponds to a $\mathrm{d}_{001}$ spacing of $3.32 \mathrm{~nm}$ based from the calculation made using the Bragg's equation. The distributor of this organoclay, Southern Clay Products, Inc. reported the $\mathrm{d}_{001}$ value for Cloisite15A to be equal to $3.15 \mathrm{~nm}$. The $\mathrm{d}_{001}$ values of this MMT derivative as determined by various authors fall in the range of $2.8-3.4 \mathrm{~nm}$ [28-31].

Pristine sodium MMT clay has $2 \theta$ value corresponding to the (001) plane lies at $8.9^{\circ}$, with a basal spacing of $9.80 \AA$ calculated from the Bragg equation [32].

As expected, the (001) peak of the organo-modified MMT clay is shifted at a lower scattering angle when the long alkyl ammonium cations were used to replace the cations originally found in the native MMT clay. A shift of the MMT characteristic diffraction peak to lower angles corresponds to an increase in the gap between two silicate platelets (larger $d_{001}$ value) and suggests that the organic surfactants were successfully intercalated in the interlayers of the host MMT clay.

Assuming a stretched configuration for the hydrogenated tallow of the ammonium modifier, the chain length was calculated based from the work of Xi et al. (2005) [33] and was estimated to have lengths between 2.4 - $3.0 \mathrm{~nm}$ taking into account that the tallow is a mixture of long alkyl chains $\left(\mathrm{C}_{14}\right.$ $\mathrm{C}_{18}$ ). To calculate the increase in the interlayer spacing brought about by the intercalation of the organic surfactants, the net difference between the calculated $\mathrm{d}_{001}$ value of Cloisite15A $(3.32 \mathrm{~nm})$ and the reported thickness of an individual MMT platelet $(0.96 \mathrm{~nm})$, was considered and the distance of the interlayer gap was determined to be $2.32 \mathrm{~nm}$ after intercalation of the tallow surfactant. Based from this calculated value and the length of a stretched tallow, it is not possible for the layer of chains to be oriented in such a way that the chains stretch out perpendicular relative to the interlayer surfaces. Vaia et al. (1994) [34]; Hackett et al. (1998) [35]; Park et al. (2004) [36] suggested a tilted paraffinic monolayer arrangement of the intercalant for an organoclay modified with an ammonium salt containing long alkyl chains. For Cloisite15A, the inner layer surfaces of an MMT clay were treated with dimethyl dihydrogenated tallow ammonium modifiers. A hydrogenated tallow alkyl chain is found to contain about 65 wt $\%$ of $\mathrm{C}_{18}, 30$ wt $\%$ of $\mathrm{C}_{16}$ and $5 \mathrm{wt} \%$ of $\mathrm{C}_{14}$ (Southern Clay Products, Inc.)

After silylation reaction of the organoclay, Cloisite15A, with a chlorosilane bearing a norbornene moiety, a decrease in the basal spacing was noted as the characteristic (001) diffraction peak of the organoclay shifted at a higher angle, $2 \theta=3.97^{\circ}\left(\mathrm{d}_{001}\right.$ $=2.22 \mathrm{~nm}$ ).

The same observation of decreased interlayer gaps after a silylation reaction using the same silane agent, norbornenechlorosilane, was reported by Guino et al.(2005) [24] on a layered silicate clay previously ion exchanged with an alkyl ammonium salt, dodecyltrimethylammonium chloride $\left(\mathrm{C}_{12} \mathrm{TMACl}\right)$. Magadiite, a layered silicate clay like MMT, is capable of incorporating guest species in the interlayer space due to the exchangeable cations located between its galleries [37-38]. Unlike MMT, however, there are reactive silanol groups on the interlayer surface which can be modified [11,39]. The alkyl ammonium modifier $\left(\mathrm{C}_{12} \mathrm{TMACl}\right)$, was first introduced in the clay structure to increase the basal spacing between the MMT platelets so that the norbornene-chlorosilane, can be 
intercalated to modify the clay surface.

After silylation, the $\mathrm{d}_{001}$ peak shifts to a higher diffraction angle $\left(2 \theta=3.97^{\circ}\right)$ which corresponds to a basal spacing of $\mathrm{d}_{001}=2.22 \mathrm{~nm}$. The decrease in the basal spacing between platelets during the silylation process is due to some alkyl ammonium salts previously intercalated between platelets of the MMT clay template being replaced by the norbornenesilane. The chain length of the silylating agent is much shorter than that of the alkyl ammonium intercalating agent, hence the smaller basal spacing observed for Cloisite15A_sil.

To establish that the loss of some amounts of ammonium modifiers is due to the result of successful silylation of the silanols on the surface of the clay template, and not on other factors (like due to stirring or reflux condition, we simulate the silylation condition without the norbornene-chlorosilane by stirring the organoclay in the same solvent (hexane) at the same condition (reflux for 48 hours under nitrogen) and getting the XRD profile of the recovered organoclay. No change in the position of the (001) diffraction peak was observed.

\subsection{Nitrogen content of Cloisite15A organoclays}

To verify that the change in the XRD profile of the organoclay during the silylation process is accompanied by the loss of some previously ionically anchored ammonium modifiers, we did a comparison of the nitrogen content of the two organoclays. The result obtained from the comparison of the nitrogen content of both organoclays (before and after silylation) complements the XRD measurements and confirms our observation that some of the alkyl ammonium modifiers previously used to modify the MMT surface were lost during the silylation process. In Table 1, the nitrogen content of the silylated clay $(0.98 \%)$ is much less than those of the unsilylated clay $(1.20 \%)$. The nitrogen content of both clays is due to the alkyl ammonium modifiers used to modify the MMT clay. The loss of some of the ammonium-based modifiers previously anchored in the galleries of the MMT template was due to its replacement by the protons generated during the silylation reaction between the silanol group of the host clay and the norbornenechlorosilane [10]. The newly formed silanols further reacted with the silylating agent as evident in the results of the XRD measurements conducted on the organoclays.

\begin{tabular}{lcccc}
\multicolumn{1}{c}{ Organoclays } & $\% \mathrm{~N}$ & $\% \mathrm{C}$ & $\mathrm{C} / \mathrm{N}$ & $\begin{array}{c}\mathbf{d}{ }^{001} \\
\text { (in nm) }\end{array}$ \\
\hline $\begin{array}{l}\text { Cloisite15A } \\
\text { (before silylation) }\end{array}$ & $1.20 \%$ & $32.0 \%$ & 26.7 & 3.32 \\
\hline $\begin{array}{l}\text { Cloisite15A_sil } \\
\text { (after silylation) }\end{array}$ & $0.98 \%$ & $35.4 \%$ & 36.1 & 2.22
\end{tabular}

Table 1. Elemental analysis and $d_{001}$ spacing of the Cloisite15A organoclays 1. táblázat Elem összetétel és $d_{001}$ távolság Cloisite15A szerves agyagokra

\subsection{Silylation of MMT_C10 organoclay}

The same silylation procedure was applied to another MMT clay derivative and the XRD profile and nitrogen content before and after the silylation were compared. The clay was an MMT derivative ion-exchanged with a decyltrimethyl ammonium bromide, $\mathrm{CH}_{3}\left(\mathrm{CH}_{2}\right)_{8} \mathrm{CH}_{2} \mathrm{~N}^{+}\left(\mathrm{CH}_{3}\right)_{3} \mathrm{Br}$. This was labeled MMT_C10. The same (001) spacing of the organoclay was observed before and after the silylation (Fig. 4). The nitrogen content also did not change (Table 2). These results suggested that in the silylation reaction of this organoclay, only the silanol groups found on the edges of the MMT_C10 clay template were modified, and not the surface, unlike in the case of Cloisite15A organoclay.

\begin{tabular}{lcccc}
\multicolumn{1}{c}{ Organoclays } & $\% \mathrm{~N}$ & $\% \mathrm{C}$ & $\mathrm{C} / \mathrm{N}$ & $\begin{array}{c}\mathbf{d}_{\mathbf{0 0 1}} \\
\text { (in } \mathrm{nm} \text { ) }\end{array}$ \\
\hline $\begin{array}{l}\text { MMT_C10 } \\
\text { (before silylation) }\end{array}$ & $1.16 \%$ & $19.3 \%$ & 16.6 & 1.42 \\
\hline $\begin{array}{l}\text { MMT_C10_sil } \\
\text { (after silylation) }\end{array}$ & $1.15 \%$ & $19.2 \%$ & 16.7 & 1.43 \\
\hline
\end{tabular}

Table 2. Elemental analysis and $d_{001}$ spacing of the MMT_C10 organoclays 2. táblázat Elem összetétel és $d_{001}$ távolság MMT_C10 szerves agyagra
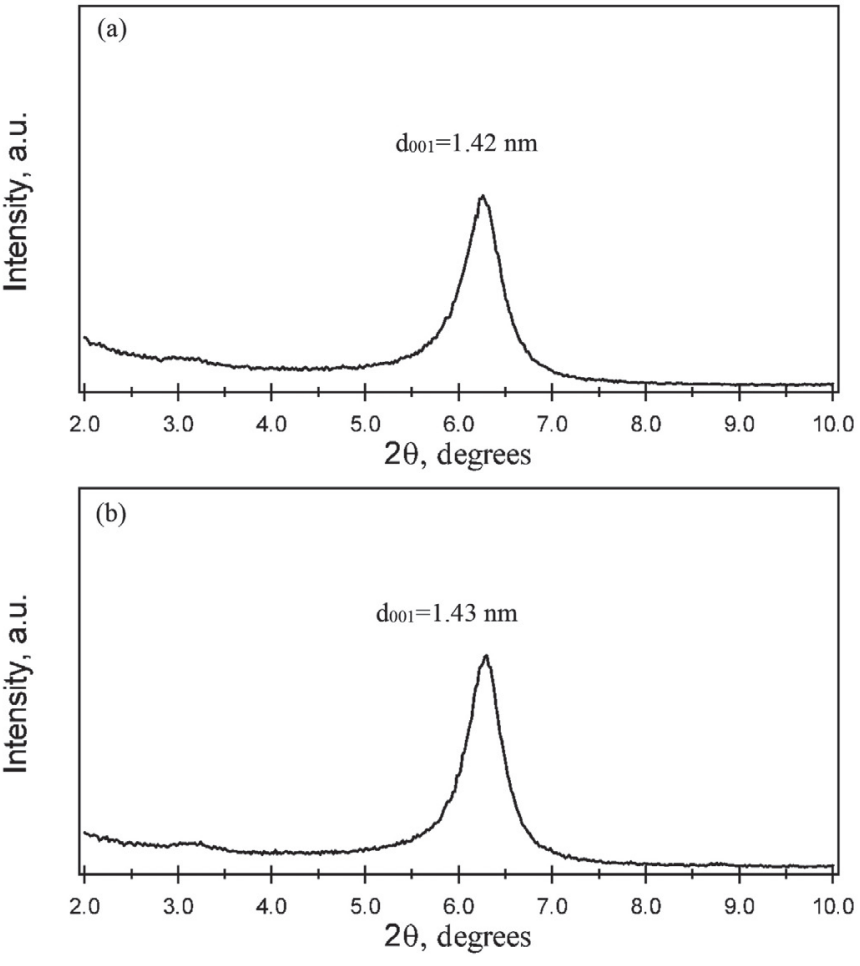

Fig. 4. XRD patterns of the (a) ion-exchanged montmorillonite clay (MMT_C10) and (b) silylated MMT_C10 (MMT_C10_sil)

4. ábra Röntgendiffraktogramok (a) ioncserélt montmorillonit agyag (MMT_C10) és (b) szilanizált MMT_C10 (MMT_C10_sil)

\section{Conclusions}

The silylation scheme results in silane-modified clays having different morphologies: (1) both surface- and edge-modified in the case of Cloisite15A and (2) only edge-modified for MMT $\mathrm{C} 10$ clay as confirmed by XRD measurements and nitrogen content analysis of both organoclays.

Using this silylation approach, a norbornene-bearing silane can be grafted on the surfaces and/or edges of the clay template. Apparently, the silylation as a way of modifying the clay morphology is affected by the length of previously attached alkyl ammonium surfactant. The ability to covalently attach the silane coupling agent having certain functional moieties, i.e. norbornene groups as initiating sites - is an important step in preparing a special class of polymer nanocomposites. 
The grafted norbornene functionalities upon the addition of a metal alkylidene can facilitate the direct polymerization on the clay surface yielding covalently bound polymer chains on an inorganic substrate.

\section{References}

[1] Xie, W. - Gao, Z. - Pan, W. P. - Hunter, D. - Singh, A. - Vaia, R. (2001): Thermal degradation chemistry of alkyl quaternary ammonium montmorillonite. Chemistry of Materials, Vol. 13, No. 9, pp. 2979-2990. https://doi.org/10.1021/cm010305s

[2] Alexandre, M. - Dubois, P. (2000): Polymer-layered silicate nanocomposites: preparation, properties and uses of a new class of materials. Materials Science and Engineering: R: Reports, Vol. 28, Nos. 1\&2, pp. 1-63 (2000). https://doi.org/10.1016/S0927-796X(00)00012-7

[3] Tjong, S. C. - Meng, Y. Z. - Hay, A. S. (2001): Novel preparation and properties of polypropylene-vermiculite nanocomposites. Chemistry of Materials, Vol. 14, No. 1, pp. 44-51. https://doi.org/10.1021/cm010061b

[4] Kotek, J. - Kelnar, I. - Studenovský, M. - Baldrian, J. (2005): Chlorosulfonated polypropylene: preparation and its application as a coupling agent in polypropylene-clay nanocomposites. Polymer, Vol. 46, No. 13, pp. 4876-4881. https://doi.org/10.1016/j.polymer.2005.02.119

[5] Pramoda, K. P. - Liu, T. (2004): Effect of moisture on the dynamic mechanical relaxation of polyamide-6/clay nanocomposites. Journal of Polymer Science Part B: Polymer Physics, Vol. 42, No. 10, pp. 1823-1830. https://doi.org/10.1002/polb.20061

[6] Zhang, Z. H. - Li, T. S. - Yang, F. - Fu, C. G. (1998): Montmorillonite clay catalysis XI: protection and deprotection of hydroxyl group by formation and cleavage of trimethylsilyl ethers catalysed by montmorillonite K-10. Synthetic Communications, Vol. 28, pp. 3105-3114. https://doi.org/10.1080/00397919808004891

[7] Tyan, H. L. - Liu, Y. C. - Wei, K. H. (1999): Thermally and mechanically enhanced clay/polyimide nanocomposite via reactive organoclay. Chemistry of Materials, Vol. 11, No. 11, pp. 1942-1947. https://doi.org/10.1021/cm990187x

[8] Herrera, N. N. - Letoffe, J. M. - Putaux, J. L. - David, L. - BourgeatLami, E. (2004): Aqueous dispersions of silane-functionalized laponite clay platelets. A first step toward the elaboration of water-based polymer/clay nanocomposites. Langmuir, Vol. 20, No. 5, pp. 1564-1571. https://doi.org/10.1021/la0349267

[9] He, H. P. - Duchet, J. - Galy, J. - Gerard, J. F. (2005): Grafting of swelling clay materials with 3-aminopropyltriethoxysilane. Journal of Colloid and Interface Science, Vol. 288, No. 1, pp. 171-176. https://doi.org/10.1016/j.jcis.2005.02.092

[10] Zhang, J. G. - Gupta, R. K. - Wilkie, C. A. (2006): Controlled silylation of montmorillonite and its polyethylene nanocomposites. Polymer, Vol. 47, No. 13, pp. 4537-4543. https://doi.org/10.1016/j.polymer.2006.04.057

[11] Okutomo, S. - Kuroda, K. - Ogawa, M. (1999): Preparation and characterization of silylated-magadiites. Applied Clay Science, Vol. 15, Nos. 1\&2, pp. 253-264. https://doi.org//10.1016/S0169-1317(99)00010-1

[12] Ogawa, M. - Okutomo, S. - Kuroda, K. (1998): Control of interlayer microstructures of a layered silicate by surface modification with organochlorosilanes. Journal of the American Chemical Society, Vol. 120, No. 29, pp. 7361-7362. https://doi.org/10.1021/ja981055s

[13] Deuel, H. - Huber, G. - Iberg, R. (1950): Organische derivate von tonmineralien. Helvetica Chimica Acta, Vol. 33, No. 5, pp. 1229-1232. https://doi.org/10.1002/hlca.19500330514

[14] Herrera, N. N. - Letoffe, J.-M. - Putaux, J.-L. - David, L. - BourgeatLami, E. (2004): Aqueous dispersions of silane-functionalized laponite clay platelets. A first step toward the elaboration of water-based polymer/clay nanocomposites. Langmuir, Vol. 20, No. 5, pp. 1564-1571. https://doi.org/10.1021/la0349267

[15] Song, K. - Sandi, G. (2001): Characterization of montmorillonite surfaces after modification by organosilane. Clays and Clay Minerals, Vol. 49, No. 12, pp. 119-125. https://doi.org/10.1002/app.12979

[16] Herrera, N. N. - Letoffe, J.-M. - Reymond, J.-P. - Bourgeat-Lami, E. (2005): Silylation of laponite clay particles with monofunctional and trifunctional vinyl alkoxysilanes. Journal of Materials Chemistry, Vol. 15, No. 8, pp. 863-871. https://doi.org/10.1039/b415618h
[17] Lee, D. C. - Jang, L. W. (1996): Preparation and characterization of PMMA-Clay hybrid composite by emulsion polymerization. Journal of Applied Polymer Science, Vol. 61, No. 7, pp. 1117-1122. https://doi.org/10.1002/(SICI)1097-4628(19960815)61:7<1117::AID-APP7>3.0.CO;2-P

[18] Park, M. - Shim, I.-K. - Jung, E.-Y. - Choy, J.-H. (2004): Modification of external surface of laponite by silane grafting. Journal of Physics and Chemistry of Solids, Vol. 65, Nos.2\&3, pp. 499-501.

https://doi.org/10.1016/j.jpcs.2003.10.031

[19] Romanzini, D. - Piroli, V. - Frache, A. - Zattera, A. J. - Amico, S. C. (2015): Sodium montmorillonite modified with methacryloxy and vinylsilanes: Influence of silylation on the morphology of clay/unsaturated polyester nanocomposites. Applied Clay Science, Vol. 114, No. 1, pp. 550557. https://doi.org/10.1016/j.clay.2015.07.003

[20] Wheeler, P. A. - Wang, J. - Baker, J. - Mathias, L. J. (2005): Synthesis and characterization of covalently functionalized laponite clay. Chemistry of Materials, Vol. 17, No. 11, pp. 3012-3018. https://doi.org/10.1021/cm050306a

[21] Bee, S. L. - Abdullah, M. A. A. - Mamat, M. - Bee, S. T. - Sin, L. T., Hui, D. - Rahmat, A. R. (2017): Characterization of silylated modified clay nanoparticles and its functionality in PMMA. Composites Part B: Engineering, Vol. 110, pp. 83-95. https://doi.org/10.1016/j.compositesb.2016.10.084

[22] Bertuoli, P. T. - Piazza, D. - Scienza, L. C. - Zattera, A. J. (2014): Preparation and characterization of montmorillonite modified with 3-aminopropyltriethoxysilane. Applied Clay Science, Vol. 87, pp. 46-51. https://doi.org/10.1016/j.clay.2013.11.020

[23] Su, L. - Tao, Q. - He, H. - Zhu, J. - Yuan, P. - Zhu, R. (2013): Silylation of montmorillonite surfaces: Dependence on solvent nature. Journal of Colloid and Interface Science, Vol. 391, pp. 16-20, https://doi.org/10.1016/j.jcis.2012.08.077

[24] Guino, R. - Lagadic, I. L. - Seery, T. A. P. (2005): Polymer nanocomposites from silica nanowafers. Abstracts of Papers of the American Chemical Society, Vol. 229, No. 2, pp. 508-INOR

[25] Jordi, M. A. - Seery, T. A. P. (2005): Quantitative determination of the chemical composition of silica-poly(norbornene) nanocomposites. Journal of the American Chemical Society, Vol. 127, No. 12, pp. 4416-4422. https://doi.org/10.1021/ja044456i

[26] Penaloza, D. P. - Sandberg, D. J. - Giotto, M. V. - Seery, T. A. P. (2015): An exfoliated clay-poly(norbornene) nanocomposite prepared by metalmediated surface-initiated polymerization. Polymer Engineering \& Science, Vol. 55, No. 10, pp. 2349-2354. . https://doi.org/10.1002/pen.24123

[27] Yavuz, M. S. - Jensen, G. C. - Penaloza, D. P. - Seery, T. A. P. - Pendergraph, S. A. - Rusling, J. F. - Sotzing, G. A. (2009): Gold nanoparticles with externally controlled, reversible shifts of local surface plasmon resonance bands. Langmuir, Vol. 25, No. 22, pp. 13120-13124. https://doi.org/10.1021/la901779k

[28] Pozsgay, A. - Frater, T. - Szazdi, L. - Muller, P. - Sajo, I. - Pukanszky, B. (2004): Gallery structure and exfoliation of organophilized montmorillonite: effect on composite properties. European Polymer Journal, Vol. 40, No. 1, pp. 27-36 (2004).

https://doi.org/10.1016/j.eurpolymj.2003.09.010

[29] Ton-That, M.-T. - Perrin-Sarazin, F. - Cole, K. C. - Bureau, M. N. - Denault, J. (2004): Polyolefin nanocomposites: Formulation and development. Polymer Engineering and Science, Vol. 44, No. 7, pp: 12121219 (2004). https://doi.org/10.1002/pen.20116

[30] Benetti, E. M. - Causin, V. - Marega, C. - Marigo, A. - Ferrara, G. - Ferraro, A. - Consalvi, M. - Fantinel, F. (2005): Morphological and structural characterization of polypropylene based nanocomposites. Polymer, Vol. 46, No. 19, pp. 8275-8285. https://doi.org/10.1016/j.polymer.2005.06.056

[31] Li, J. - Ton-That - M.-T. - Tsai, S.-J. (2006): PP-based nanocomposites with various intercalant types and intercalant coverages. Polymer Engineering \& Science, Vol. 46, No. 8, pp. 1060-1068. https://doi.org/10.1002/pen.20552

[32] Figueras, F. (1998): Pillared clays as catalysts. Catalysis Reviews: Science and Engineering, Vol. 30, No. 3, pp. 457 - 499. https://doi.org/10.1080/01614948808080811

[33] Xi, Y. - Frost, R. L. - He, H. (2007): Modification of the surfaces of Wyoming montmorillonite by the cationic surfactants alkyl trimethyl, dialkyl dimethyl, and trialkyl methyl ammonium bromides. Journal of Colloid and Interface Science, Vol. 305, No. 1, pp. 150-158. https://doi.org/10.1016/j.jcis.2006.09.033 
[34] Vaia, R. A. - Teukolsky, R. K. - Giannelis, E. P. (1994): Interlayer structure and molecular environment of alkylammonium layered silicates. Chemistry of Materials, Vol. 6, No. 7, pp. 1017-1022. https://doi.org/10.1021/cm00043a025

[35] Hackett, E. - Manias, E. - Giannelis, E. P. (1998): Molecular dynamics simulations of organically modified layered silicates. Journal of Chemical Physics, Vol. 108, No. 17, pp. 7410-7415. https://doi.org/10.1063/1.476161

[36] Park, C. I. - Kim, M. H. - Ok Park, O. (2004): Effect of heat treatment on the microstructural change of syndiotactic polystyrene/poly(styreneco-vinyloxazolin)/clay nanocomposite. Polymer, Vol. 45, No. 4, pp. 12671273. https://doi.org/10.1016/j.polymer.2003.12.011

[37] Eugster, H. P. (1967): Hydrous sodium silicates from Lake Magadi, Kenya: Precursors of bedded chert. Science, Vol. 157, No. 3793 , pp. 1177-1180. https://doi.org/10.1126/science.157.3793.1177
[38] Rojo, J. M. - Ruiz-Hitzky, E. - Sanz, J. (1988): Proton-sodium exchange in magadiite. Spectroscopic study (NMR, IR) of the evolution of interlayer OH groups. Inorganic Chemistry, Vol. 27, No. 16 , pp.2785-2790.

https://doi.org/10.1021/ic00289a009

[39] Theng, B. K. G. (1974): The Chemistry of Clay-Organic Reactions. Adam Hilger.

\section{Ref.:}

Penaloza Jr., David P. - Seery, Thomas AP: Silylated functionalized montmorillonite clay for nanocomposite preparation Építöanyag - Journal of Silicate Based and Composite Materials, Vol. 70, No. 5 (2018), 140-145. p.

https://doi.org/10.14382/epitoanyag-jsbcm.2018.26

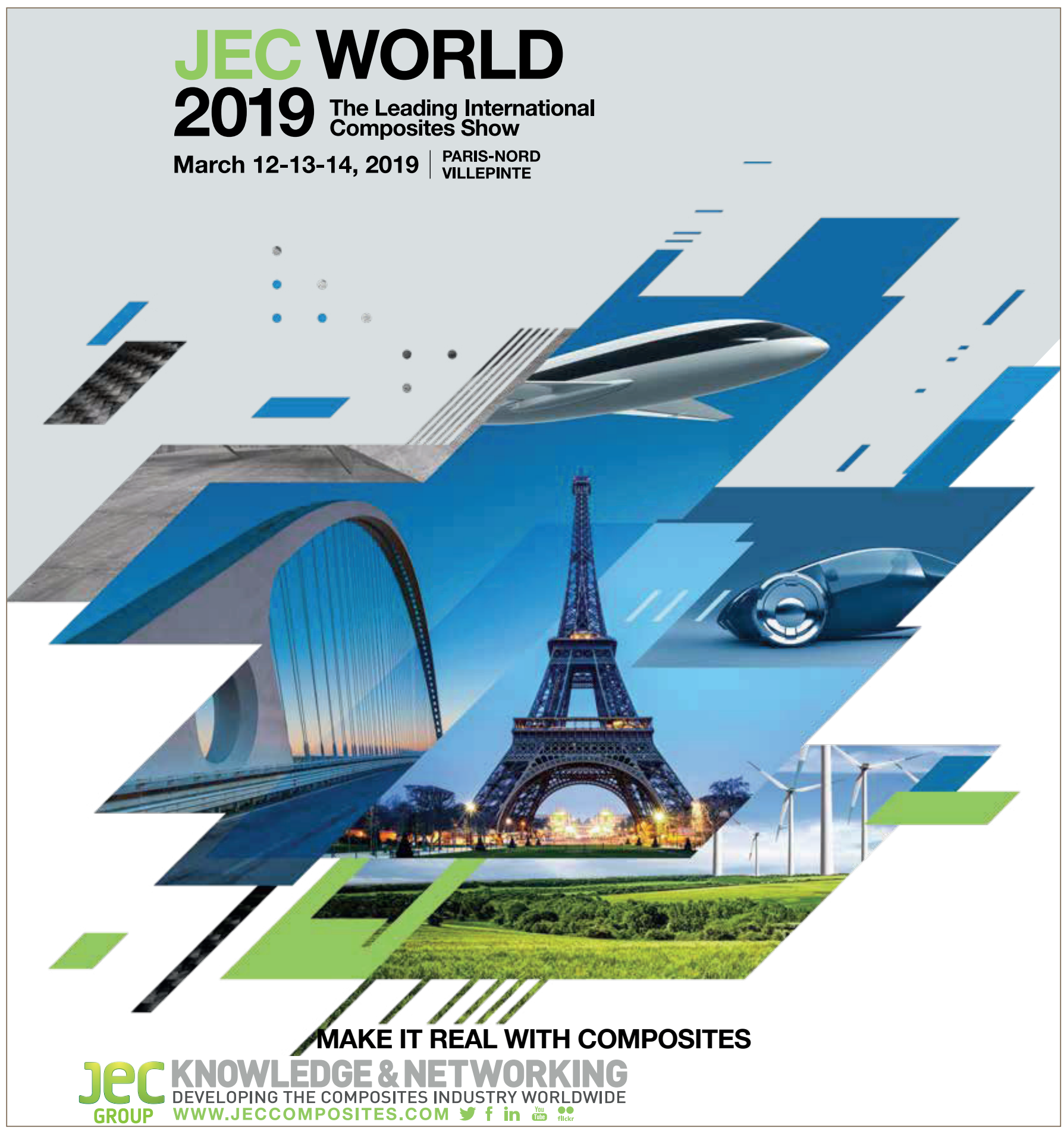

